UNRAM Law Review is licensed under a Creative Commons Attribution 4.0 International License, which permits unrestricted use, distribution, and reproduction in any medium, provided the original work is properly cited. ISSN: 2548-9267 | e-ISSN: 2549-2365._Open Access at: http://unramlawreview.unram.ac.id/index.php/ulr/user

\section{Volume}

1

Issue

1
Page
$0-131$
April

2017
ISSN: 2548-9267

E-ISSN: 2549-2365

\title{
Regulation and Supervision of Sharia Banking According to Indonesian Legislation
}

\author{
Muhammad Sood \\ Faculty of Law Mataram University \\ St. Majapahit No. 62 Mataram 83125, Telp. (0370), 633035, Fax. 626954 \\ Email:msood@gmail.com
}

H. Muhaimin

Faculty of Law Mataram University

St. Majapahit No. 62 Mataram 83125, Telp. (0370), 633035, Fax. 626954

Email: mmuhaimin@gmail.com

\author{
Hj. Sumiyati Ismail
}

Faculty of Law Mataram University

St. Majapahit No. 62 Mataram 83125, Telp. (0370), 633035, Fax. 626954

Email: itasurayya@gmail.com

\begin{abstract}
The purpose of this research is to analyze the regulation and supervision of Sharia banking business according to positive law in Indonesia, while the target is to be achieved, first, to analyze the regulation of Sharia banking supervision institution of according the positive law; Second, the existence of the institution of Sharia banking supervision, comparison of Sharia banking supervision that conducted by Bank Indonesia, the Financial Service Authority (FSA), the Board of Commissioners, and Board of Sharia Supervisory (BSS) according to Indonesian positive law. The gathering of legal materials conducted through the study of literature, then conducted a qualitative descriptive analysis to obtain a prescriptive conclusion deductively. The result of research shows that the regulation and supervision of Sharia banking in Indonesia at first is the authority of Bank Indonesia, then change judicially to become the authority of the FSA. The supervision of Sharia bank internally is also the authority of the Board of Commissioner and ShariaBSS as stipulated in the Banking Law of Sharia and Limited Company Law. Base on the result of research, there are inconsistent or conflict of norm about authority among institutions on regulation and supervision of banking. The problem can cause the legal uncertainty in the implementation of its functions, duties and authority of the FSA as an institution that is mandated by law in conducting regulation and supervision of banking. Therefore, it necessary to regulate comprehensively about Sharia banking supervision in an article or provision clearly and comprehensible, because of there are differences of the characteristics of Sharia banking activities.
\end{abstract}


Keywords: regulation, supervision, sharia banking.

\section{INTRODUCTION}

Dual banking system is a banking system that applied in Indonesia, besides conventional banking also Sharia banking. Both of these systems simultaneously apply both de facto and de jure, it is as a result of the need for the importance of participation of all components of society in national development, especially in the banking sector. To support the implementation of these two systems are required its regulation and supervision base on the positive law, so that it has the same status as part of the legal system of national banks. However, there are still many problems that can be implications legally of the existence of Sharia banking business in conducting business in Indonesia.

Various regulation and supervision of sharia banking in the system of national banking laws, among others, Act Number 23 Year 1999 on Bank Indonesia as amended by Act Number 3 Year 2004 and amended again a second time by Act Nunber 6 Year 2009; Act Number 7 Year 1992 on Banking as amended by Act Number 10 Year 1998, Act Number 21 Year 2008 on Islamic Banking, and Act Number 21 Year 2011 on the Financial Services Authority.

The number of regulations on supervision of Islamic banking does not always giving legal certainty guarantee in the implementation of the duties and authority of the banking supervisory agencies in the effort of institutional management and banking bussiness activity. Regulation and supervision of Islamic banking in the legislation even cause blurring of norms and can couse to conflict or disagreement norm. The blurring of norms that occured in regulation and supervision of Islamic banking is such as authority regulation on Sharia compliance in Islamic banking.

The contradiction is seen in Article 34 sectio (1) of Act Number 23 Year 1999 on Bank Indonesia, mandates that: "The duty of bank supervision will be conducted by the supervisory board of financial services sector that independent, and is formed by legislation. However, after the issuance of Act Number 21 Year 2011 on the Financial Services Authority (FSA Act), Article 5 and Article 6 states that: FSA has the function to carry out the regulatory and supervisory system that is integrated to the whole of activities in the financial services sector ". The blurring of norms raises the juridical question, which one of institutions that has the right to regulate and supervise banks including in Islamic banking, is the central bank still responsible for organizing and supervising the Bank, or the FSA are only entitled to regulate 
and supervise the Bank, or both are still entitled to organize and supervise the Bank.

The blurring and contradiction of norms give rise to differences of interpretation both legally and in practice, so can result in legal problems in the implementation of the provisions of the regulation and supervision of Islamic banking. Because of still unclear legal rules governing the banking supervision related to the implementation of Sharia, so it is necessary to a thought and study on regulation and supervision of Islamic banking, so that in practice it does not happen the legal issues, with expectation in its implementation can be in line with the positive law and not contrary to Sharia Principle. This research will analize a thought to measure a possibilities konfrehensifly about sharia banking supervision in provision of a clear and comprehensible, because of the differences of characteristics in Islamic banking activities.

Base on the explanation above, there are two essential legal issues in this research consist of:

1. How is the regulatian and supervision of sharia banking in Indonesia?

2. How is the role of Islamic banking supervisory agency according to positive law of Indonesia?

\section{RESEARCH METHODS}

This research is a doctrinal or normative law $^{1}$ that sees the law as a rule or the text of the legislation (law in the books). In connection with the issues raised is the existence of sharia banking supervisory agency according to the positive law expected to be obtained on the existence of an integral understanding of the sharia banking supervision according to the legislation in Indonesia. The approach used statute approach, conceptual approach and the comparative approach. ${ }^{2}$

This research was conducted in the Library, both Public Libraries and Mataram University Library, Law Faculty Library, special collections Notary Master Program as well as available libraries of digital/online through internet media.

This research uses secondary data, is the data obtained from library materials (material law) namely; primary, secondary and and tertiary legal materials, which include: a written document, which is derived from legislation, court decisions, literature and sources of Islamic law, including the decisions issued by the Muslim community organizations both local scale national and international such as; National Sharia Board Fatwa of MUI, result of research,

\footnotetext{
${ }^{1}$ Soerjono Soekanto and Sri Mamudji (1995) Normative Legal Research, Jakarta : RadjaGrafindo Persada, page 15

${ }^{2}$ Peter Mahmud Marzuki (2004) Legal Research, Jakarta: Kencana,page. 20
} 
scientific articles, literature books, official documents, archives, dictionaries and encyclopedias related to sharia.

Data required in this study, will be collected through the study of literature (liabrary research) or the study of documents that conducted in stages as follows:

1. In the early stages, will be carried out literature studies that carried out by inventory of legislation, court decisions, books and other literature as secondary data sources become the focus of research. This method is done to obtain a description of a general nature and thoroughly, about what is included in the focus of issue that will be anaized on the existence of sharia banking supervisory agency according to the positive law.

2. Studies document, which examined the various documents and legal materials relating to the cases studied, especially legislation, court decisions and arbitration, as well as literature relating to the sharia, especially about Islamic banking supervision.

In accordance with the method used, so in this research analysis used based on the doctrinal approach is analyzed using qualitative analysis methods. In this phase, researchers conducted an inventory and collection of legal materials related to the supervision of the sharia banking, then organized into a comprehensive system. After collection of the overall principles and the rule of law in a comprehensive system, then conducted classification and validation of all the rules of law, and then conducted a legal interpretation to develop legal argument in order to be concluded as deductive perspective.

\section{ANALYSIS AND DISCUSSION}

\section{Regulation and Supervision of Sharia Banking by Banking Institutions Supervisors According to the Positive Law of Indonesia.}

\section{Regulation and Supervision of Sharia Banking by Bank Indonesia (BI).}

1) Functions and Authority of Bank Indonesia before the Act Number 21 Year 2011 on the Financial Services Authority (FSA).

The function and authority of Bank Indonesia to conduct guidance and supervision of banking, before the formation FSA regulated in Article 29 of Act Number 10 Year 1998 on banking, which states:

(1) Guidance and supervision of banks conducted by Bank Indonesia.

(2) Banks have to maintain the soundness of banks in accordance with the provisions of the capital adequacy, asset quality, management quality, liquidity, profitability, solvency, and 
other aspects related to the business of the bank, and shall conduct business activities in accordance with the prudential principle.

(3) In providing credit or financing based on sharia principle and conduct the other business activities, banks are obliged to follow in ways that do not injury the interests of the bank and the customers who entrust their funds to banks.

(4) For the sake of customers, banks are obliged to provide information on the likelihood of the risk of losses related to customer transactions made through banks.

(5) The role that must be fulfilled by the bank referred to in section (2), (3) and (4) determined by Bank Indonesia.

Furthermore, in Article 30 states that:

(1) Banks are required to submit to Bank Indonesia, all the information and explanations concerning its business according to the procedures stipulated by Bank Indonesia.

(2) Bank at the request of Bank Indonesia, are required to provide an opportunity for inspection of books and records available to him, and shall provide the necessary assistance in order to obtain the truth of any information, documents and explanations that are reported by the bank concerned.

(3) Description of the banks is obtained base on the provisions referred to in section (1) and (2) are not announced and confidential.

After Bank Indonesia except the bank documents, and then conduct an examination of the Bank, as defined in Article 31, states that:

(1) Bank Indonesia conducts an examination of the bank, either periodically or every time if necessary.

(2) If required to establish the policies macro of monetary council can ask the Bank Indonesia:

a. to submit a report on the results of bank examinations are required;

b. to conduct special examination towards the bank, and reported the results of the examination were conducted.

The inspection reports as referred to in Article 31 and Article $31 \mathrm{~A}$ are confidential, the terms and procedure as referred to in Article 31 and Article 31 A determined by Bank Indonesia. Furthermore in Article 34 states that, 
(1) Banks are required to submit to Bank Indonesia the balance sheet and calculation of annual profit and loss, and its description, as well as other periodic reports, in time and form determined by Bank Indonesia.

(2) Balance sheet and calculation of annual profit and loss referred to in section (1) must be audited by a public accountant.

(3) The fiscal year of bank is the calendar year.

As with the issuance of Act Number 3 Year 2004 on Bank Indonesia, that the duties supervisory of Bank in Indonesia conducted by the independent supervisory agencies, it is affirmed in Article 34 which states that,

(1) The duty of supervision of the Bank will be carried out by the supervisory board of independent financial services sector that is formed by legislation.

(2) The establishment of supervisory institutions referred to in section (1) shall be implemented maximum December 31, 2010.

However, with the enactment of the Act Number 21 Year 2008 on Sharia Banking, the existence of the Shariah banking system in the banking system in Indonesia has earned the highest legal umbrella that will protect the business activities of the Islamic banking industry in Indonesia. It is with be receipted of the Bill of sharia banking become the Act Number 21 Year 2008 on Sharia Banking (Sharia Banking Act), which was legalized on July 16, 2008.

The effort of guidance and supervision of sharia banking affirmed in Article 50 of the Sharia Banking Act which states that, "Development and supervision of Sharia Banking and Sharia Business Unit (SBU) conducted by Bank Indonesia". According to these provisions means that Bank Indonesia has two heavy duties mainly as the builder of sharia banks, which requires Bank Indonesia to conduct supervision to Islamic banks to be able to adjust to the Islamic banking system at a time to align itself with the existence of conventional banking which had already existed. On the other hand, Bank Indonesia also has duty to supervise the sharia banking in Indonesia.

In connection with the efforts of development and supervision conducted by Bank Indonesia, so the sharia banking must maintain the level of health. This is confirmed in Article 51 Sharia Banking Act stating that,

(1) The Islamic Bank and Sharia Act must maintain a level of health that includes at least about capital adequacy, asset quality, liquidity, profitability, solvency, quality of 
management that describes the capabilities of the financial aspects, compliance with Sharia principles and the principles of Islamic management, as well as other aspects related to the business of Islamic Bank and Sharia Act.

(2) The criteria of health level and the rull that must be fulfilled by the Sharia Bank and Sharia Act as referred to in section (1) is regulated by Regulation of Bank Indonesia.

In accordance with the provision above, Sharia Bank and Sharia Act must submit any information its business activities to Bank Indonesia, it is confirmed in Article 52 Sharia Act stating,

(1) The Sharia Bank and Sharia Act must submit all the information and explanations on their efforts to Bank Indonesia in accordance with procedures that determined by the Regulation of Bank Indonesia.

(2) Bank of Sharia and Sharia Act, at the request of Bank Indonesia, are required to provide an opportunity for inspection of books and records available to him, and shall provide the necessary assistance in order to obtain the truth of any information, documents and explanations are reported by that Sharia Bank and Sharia Act.

(3) In the framework of the implementation of supervisory duty as referred to in section (1) and (2), Bank Indonesia has the authority:

a. To inspect and retrieve data/documents from any place related to the Bank;

b. To inspect and retrieve data/documents and information from each of the parties, according to Bank Indonesia has an influence on the Bank;

c. To instruct toward Bank to block certain accounts, both accounts savings and financing account.

(4) Information and inspection reports on Sharia Bank and Sharia Act that obtained base on the provisions referred to in section (1), (2) and (3) are not announced and confidential.

In order to carry out the supervisory duty, Bank Indonesian can assign the public Acountant as defined in Article 53 as follows:

(1) Bank Indonesia can assign public accounting firms or other parties for and on behalf of Bank Indonesia, carry out the examination referred to Article 52 section (2).

(2) The requirement and procedure as referred to in section (1) is regulated by Regulation of Bank Indonesia. 
According to the provisions above, that Islamic Bank and Sharia Act must submit all the information about their business to be inspected by Bank Indonesia, including: books, papers and other documents; and shall provide the assistance required by Bank Indonesia in order to obtain the truth of any information, documents and explanations report.

Functions and Authority of the Bank Indonesia After the Act Number 21 Year 2011 on the Financial Services Authority

Transfer planning of supervisory functions of Bank Indonesia to a new institution called the Financial Services Authority (FSA) should be considered carefully and cautiously. Therefore it is necessary to analyze closely the experience of countries that have done the same thing, including the possible adverse impact on the stability of the monetary and financial system. If the transferee in the end had to be done, is expected to be cautious and gradual, and through a process of careful preparation, both in terms of institutional and human resources. $^{3}$

However, the Government especially the Ministry of Finance still intends to separate the functions of supervision of Bank Indonesia and incorporate them into the financial services supervisory agency that is now as a Financial Services Authority (FSA) is due to several reasons stated as follows: ${ }^{4}$

a. The financial system which is based on the financial sector likely to cause systemic risk.

b. The weakness of regulation and supervision of the financial sector conglomerates

c. The globalization of the financial sector caused many financial transactions between countries so the existence foreign financial institution could threaten the domestic financial sector

d. Anti-money laundering

e. The growing financial institution products (e.g. unit-linked products and universal banking) are interlinked, so that it difficult for authorities to make the boundary demarcation of authority.

With the issuance of the Act Number 21 Year 2011 on the Financial Services Authority (FSA) was legalized on November 22, 2011, has moved the duties and authority of Bank Indonesia (BI) on the regulation and supervision of banking in Indonesia. Bank Indonesia

\footnotetext{
${ }^{3}$ Shayril Sabirin, (2003),Struggle Out of Crisis, Yogyakarta : BPFE, page 14

${ }^{4}$ Anton Purba in Nasution Darmin (2003), Thought Conception of the Financial Services Authority, page 178
} 
only has a role in monetary policy is to maintain the stability of rupiah value. Functions, duties and authority of regulation and supervision of financial services activities of the Banking sector have turned to the Financial Services Authority (FSA) since December 31, 2013. Similarly, the functions, duties and powers of regulation and supervision in the sector of the Capital Market and Non-Bank Financial Institutions will move to the FSA since December 31, 2012.

After establishment of FSA, Bank Indonesia will focus on the authority only in terms of monetary policy are the policies to achieve and maintain rupiah stability are among others: through controlling inflation and exchange rates, the money supply, or the interest rate. This role can cause problems when the central bank that BI does not have access to comprehensive information about bank supervision sector. The central bank can basically put out the monetary policy due to pick the bank supervisory authority. In anticipation of this, it needs good coordination between the FSA and the BI, so that BI still exists in supporting the Indonesian economy.

After the authority of BI moves to FSA, so the function of BI as a lender of last resort only. Monetary policy is a policy that is to achieve and maintain stability in the rupiah which is conducted through the control of the money supply or interest rates. This role may eventually there will be a problem when the central bank that BI does not have access to comprehensive information about bank supervision sector. Therefore, the central bank can issue a good monetary policy because it has a bank supervision authority. In anticipation of this, we need good coordination between the FSA and the Bank of Indonesia, so that Bank Indonesia still obtains direct access to the banking sector.

\section{Regulation and Supervision of Islamic Banks by the Financial Services Authority (FSA)}

To implement the national economy that is able to grow in a sustainable and stable required activities in the financial services sector are held regularly, fair, transparent and accountable and be able to realize the financial system to grow in a sustainable and stable, and capable of protecting the interests of consumers and the public, so that the necessary FSA which has the functions, duties, and authority to regulate and supervise the activities in the financial services sector in an integrated, independent and accountable.

Therefore, since December 31, 2012, the functions, duties and authority of the regulatory and supervisory activities of the financial services sector Capital Markets, Insurance, Pension Funds, Financing Agency and the Institute of Financial Services Other 
switch from the Capital Market Supervisory Agency and Financial Institution (Ministry Finance) to the Financial Services Authority (FSA). Thus since the functions, duties and authority of regulation and supervision of financial services activity in the banking sector moved from BI to the FSA. Regulation and supervision of the institutional, health, aspects of prudential and bank inspection is the scope of micro prudential regulation and supervision that become duties and authority of the FSA. As for the scope of macro prudential regulation and supervision is the duty and authority of the central bank. Therefore, the authority of BI is only in terms of monetary policy as the policies to achieve and maintain stability in the rupiah which is done through the control of inflation and exchange rates, the money supply, and or interest rate.

To support the transition of functions, duties and authority of regulation and supervision of Bank Indonesia to the FSA, so since the enactment of Act Number 21 Year 2011 on the Financial Services Authority (FSA), the institute aims as regulated in Article 4 is that the financial services sector,

a. held regularly, fair, transparent and accountable;

b. able to realize the financial system in a sustainable and stable growth; and

c. able to protect the interests of consumers and the public

The function of the FSA is to supervise all business activities in relating to the financial sector in Indonesia. This is stated in Article 5 that "the FSA has function to organize the regulation and supervision system that is integrated to the overall activity in the financial services sector, one of which is regulating and monitoring of business activity in the banking sector.

Further, the duty of FSA is regulated in Article 6 which states, "the FSA implements regulation and supervision duties to:

a. Financial services activities in the banking sector;

b. Financial services activities in the capital market sector; and

c. Financial services activities in the sector of Insurance, Pension Funds, Financing Institutions and Other Financial Services Institutions.

To carry out the duty of regulation and supervision, the FSA has the authority as defined in Article 7 which states, 
a. Regulation and supervision on the bank Institution that includes:

1) The licenses for the establishment of banks, opening bank offices, the basic budget, work plan, ownership, management and human resources, mergers, consolidation and acquisitions of banks, as well as the bank's license revocation;

2) The business activities of the bank, among other sources of funds, provision of funds, hybridization product, and activity in the service sector;

b. Regulation and supervision of the health of banks include:

2) The liquidity, profitability, solvency, asset quality, capital adequacy ratio minimum, lending limits, the ratio of loans to deposits, and bank reserves;

3) The bank report relating to the health and performance of the bank;

4) The debtor information system;

5) The Examination of Credit (credit testing);

6) The bank accounting standards;

c. Regulation and supervision of the bank's prudential aspects, including: 1. management; 2 . The governance of the bank; 3. The principle to know customer and anti-money laundering; and 4. the prevention of terrorism financing and banking crimes; and

d. Bank examination.

Furthermore, according to Article 8, that to carry out the regulation duty referred to Article 6, the FSA has the authority to:

a. establish the implementation of regulations of this Act;

b. establish the legislation in the financial services sector;

c. establish the FSA rules and decisions;

d. establish the rules regarding supervision in the financial services sector;

e. establish on policies regarding the implementation of the FSA duty;

f. establish the rules concerning procedures for establishing a written order of the Financial Services Institute and a particular party; 
g. Then in Article 9 states that, "to carry out the duty of supervision that establish rules concerning procedures for establishing the statutory manager at the Institute of Financial Services;

h. To establishes the organizational structure and infrastructure, as well as manage, maintain, and administer its assets and liabilities; and

i. To establish the rules concerning the procedures for the imposition of sanctions in accordance with the provisions of the legislation in the financial services sector.

As referred to in Article 6, the FSA has the authority to:

a. establishes the operational policy of supervision towards the financial services activities;

b. supervise the implementation of supervisory duty carried out by the Chief Executive;

c. conduct surveillance, inspection, investigation, protection of consumers, and any other action against the Institute of Financial Services, the offender, and/or supporting the activities of the financial services referred to the legislation in the financial services sector;

d. provide a written order to the Institute of Financial Services and/or a particular party;

e. appoint statutory managers;

f. establish the appropriation of the statutory manager;

g. establish the administrative sanctions against the party who conduct violations of the legislation and regulations in the financial services sector; and

h. provide and / or to repeal: 1) the business license; 2) The individual licenses; 3) the effectiveness of the registration statement; 40 letter registered mark; 5) approval to conduct business; 6) legalization; 7) approval or determination of dissolution; and 8) other determination.

Regulation and Supervision of Sharia Banking by the Board of Commissioners and Sharia Supervisory Board (SSB)

\section{Regulation and Supervision of Sharia Banking by Board of Commissioners}

According to Article 1, item 6 of the Act Number 40 Year 2007 on Limited Company (Company Act), it is stated that, "Board of Commissioner (BOC) is the organ of the company in charge of supervising the Company generally and/or special accordance with the statutes and to provide advice to the Board of Directors (BO)". As an organ of the company, the 
Board has an important responsibility in supervising the company operational activity

The company's business activity monitoring conducted by the Board of Commissioners has been regulated in Article 108 of Act Number 40 Year 2007 on Limited Company (Company Act) which states:

(1) The Board of Commissioners shall supervise the management policies, the activity of management in general, both regarding the Company or the Company's business, and to advise the Board of Directors.

(2) Supervision and provision of advice as referred to section (1) is done for the benefit of the Company and in accordance with the aims and objectives of the Company.

(3) the Board of Commissioners consists of 1 (one) member or more.

(4) The Board of Commissioners consists of more than 1 (one) member of the council and each member of the Board of Commissioners cannot act alone, but by the decision of the Board of Commissioners.

Based on the article above, that the Board of Commissioners supervise the management policies, the activity of management in general, both regarding the Company or the Company's business, and to advise the Board of Directors. Supervision and the administration are for the benefit of the Company and in accordance with the aims and objectives of the Company. The Board of Commissioners consists of 1 (one) member or more. The BOC is more than 1 (one) member of the council and each member of the Board of Commissioners can not act alone, but by the decision of the Board of Commissioners

\section{Supervision of Islamic Banking by the Sharia Supervisory Board (SSB)}

Besides having the organ of Board of Commissioner (BOC), in the sharia financial institutions also has the organ of Sharia Supervisory Board (SSB) which is the body charged with overseeing implementation of the decision of the National Sharia Board (NSB) in the Islamic financial institutions. The provision concerning the Sharia Supervisory Board (SSB) has been regulated in Article 109 of Act Number 40 Year 2007 on the Company Limited (Company Law) which states that:

(1) The company that runs business activities based on sharia principles in addition to having the Board of Commissioners shall have the Sharia Supervisory Board. 
(2) Sharia Supervisory Board referred to in section (1) consist of an expert on sharia or more appointed by the General Meeting of Share Holder on the recommendation of the suitable to sharia principles.

Furthermore on the provisions regarding the establishment of SSB as defined in Article 32 of the Act Number 21 Year 2008 on Sharia Banking Act (SBA), which states,

(1) The Sharia Supervisory Board shall be established in Sharia Banking and Conventional Commercial Bank having a Sharia Act.

(2) The Sharia Supervisory Board referred to in section (1) shall be appointed by the General Meeting of Shareholders on the recommendation of the Indonesian Ulama Council.

(3) The Sharia Supervisory Board referred to in section (1) shall provide advice and suggestions to the Board directors and oversees the activities of the Bank to comply with Sharia principles.

(4) A further provision on the establishment of Sharia Supervisory Board is referred to in section (1) is regulated by Bank Indonesia.

Base on the provisions above, that the Sharia Supervisory Board must be established in the Sharia Bank and Commercial General Bank which owned by Sharia Business Unit (SBU). Sharia Supervisory Board appointed by the General Meeting of Shareholders on the recommendation of the Indonesian Ulama Council. The Sharia Supervisory Board assigned with providing advice and recommendations to the board of directors and supervises the activities of the Bank to comply with Sharia principles.

\section{Existence of Sharia Banking Supervisory Board According the Positive Law of Indonesia}

\section{Existence of Bank Indonesia in Supervision Sharia Banking.}

Bank Indonesia as the central bank holds the authority of guidance and supervision of banks that invested with authority with regard to licensing, issuing provisions on healthy banking activity, as well as supervise and provide guidance to the bank in carrying out any banking business with the aim of encouraging the establishment of a healthy banking system. The banking supervision activity is the implementation of monetary supervision with a view to monitor and to know the financial institution in this case to comply with the rules of law that determined by Bank Indonesia as the monetary authority and run the banking business. ${ }^{5}$

5 Jaslen Sardanto Purba, (1998), The Role of Bank Indonesia in Supervision and Development Bank in Indonesia (A Yudicial Review), Result of Reseach, Law Faculty, Medan : University of North Sumatera. 
The existence and role of Bank Indonesia in supervision of the bank's business activities both conventional banks and Islamic banks based on Article 29 section (1) of Act Number 10 Year 1998 as amendments to the Act Number 7 Year 1992 on Banking, which state that, "Guidance and supervision of bank conducted by Bank Indonesia". In connection with the guidance and supervision, Bank Indonesia has the duty of which is based on Article 8 of Act Number 3 Year 2004 on the Amendment to Act Number 23 Year 1999 concerning Bank Indonesia, which states that, "To achieve the objectives referred to Article 7, Bank Indonesia has the following duty: a) establish and implement monetary policy, b) regulate and maintain fluency of operation of payment systems, c) regulate and supervise banks", Furthermore, in Article 50 of Act Number 21 Year 2008 as regulation specifically regulating sharia banking is mentioned that "guidance and supervision of sharia banks and Sharia Act conducted by Bank Indonesia".

In an effort to implement the regulation and supervision of banks, Bank Indonesia has what authority: ${ }^{6}$

(1) The authority to give license (right to license), which is the authority to establish licensing procedures and the establishment of a bank. Scope providing license by the Bank Indonesia include providing and revoking business license of banks and providing the opening license, closing and moving bank office, the approval of the ownership and management of banks, granting permission to banks to carry out certain business activities.

(2) The authority to regulate (right to regulate), the authority to establish regulations concerning aspects of the business and banking activities in order to create a healthy banking which are able to fulfill the banking services that expected by public.

(3) The authority to supervise (right to control), which is the authority to supervise banks through direct supervision (on-site supervision) and indirect supervision (off-site supervision). Direct supervisor such as a general inspection and special inspection, which aims to get an overview of the bank's financial situation and to monitor the level of banks compliance towards the regulations as well as to know whether there are practices that are unhealthy that endanger the survival of a banking business.

${ }^{6}$ Choirul Anwar, (2010), Supervision mechanisms of Sharia Supervisory Board and Bank Indonesia towards Sharia Jateng Bank In Surakarta, Thesis of Program Master of Law Faculty of University of March Surakarta. 
(4) The authority to impose sanctions (right to impose sanction), which is the authority to impose sanctions in accordance with the provisions of legislation on the bank if a bank is less or does not fulfill the requirement. This action contains elements of guidance in order to bank operates in accordance with the healthy banking the principles.

As for the implementation of the guidance and supervision of bank, which is the bank supervisory authorities in Indonesia, consist of:

(1) Monitoring the financial condition of banks, in particular the level of health or aspects of the fulfillment of capital/Capital Adequacy Ratio (CAR); quality of productive assets; management, rent ability, liquidity and sensitivity to market-oriented risk base on the principle of prudence in creating the stability of the financial system.

(2) Application of the prudential guidelines that must be obeyed by bank, such as the obligations of fulfilling minimum capital, lending limits of loan, the level of problem loans that must be preserved, position of net foreign exchange, liability establishment of reserves for eradication of problem earning assets, statutory reserves which should be maintained, implementation of the principle of know your customer in relation to antimoney laundering, the regulation concerning the transparency of bank financial condition in connection with public reporting.

(3) The application of self-regulatory banking, such as the obligation to make the bank's credit policies, the internal audit unit, the appointment of the director of compliance and reporting to BI, risk management practices, and so on.

(4) If there are deviations regulations or there is a potential risk, Bank Indonesia will conduct guidance in the form of reprimand, warning and calling the manager (Board of directors/commissioners) bank in the form of letter of official warnings, restrictions or prohibition on certain activities such as participation clearing, opening branch offices, prohibition on lending credit, reduction of healthy level of bank, replacement of management, and inclusion of the blacklist.

(5) If Bank Indonesia find the presumption of banking criminal act (general crime) or violation of the Act (special crime) on the basis of information/allegations that have been proven by the results of the inspection, BI shall follow up these findings base on the Decree of General Attorney Republic of Indonesia, Chief of Police Republic of Indonesia, and the Governor of Bang Indonesia.

Thus in outline, Bank Indonesia has had a tiered standard monitoring procedure. Its 
starting from the notification, confirmation through the invocation of directors and commissioners of banks, special inspections, warning letters, the obligation to perform corrective measures, the obligation commissioner of further steps including specific crime and general crime, monitoring repair and sanctioning with fixed base to bank secrecy to maintain public confidence and the stability of the financial system.

\section{Extension of the Financial Services Authority (FSA) in Islamic Banking Supervision}

To support the implementation of supervisory duty in the financial services sector, since December 31, 2012, the government issued the Act Number 21 Year 2011 on the Financial Services Authority (FSAA). Thus, the functions, duties and authority of the regulatory and supervisory activities of the financial services in Sector of Capital Markets, Insurance, Pension Funds, Financing Agency and the Institute of Financial Services Other switch from the Capital Market Supervisory Agency and Financial Institution firstly located at the Ministry of Finance to the Service Authority Finance (FSA). Similarly, the functions, duties and powers of supervising and regulating the activities of financial services in the Banking Sector switch from Bank Indonesia to the FSA, either regulation or supervision of the institutional, health, prudential aspects, or inspection of the bank are the scope of the regulatory and supervisory duty become authority of FSA. With switching functions, duties and authority of $\mathrm{BI}$ to the FSA then position the FSA is very strong in regulated and supervised banking. However, the FSA in the implementation of the functions, duties and authorities usually coordinate with Bank Indonesia to support Banking business activity.

With the promulgation of Act Number 21 Year 2011 on the Financial Services Authority (FSAA) is the legal basis of the FSA as an independent agency to carry out the functions, duties and authority of regulation and supervision of financial services activity in the banking sector. This is confirmed in Article 1 which states that "the Financial Services Authority, hereinafter abbreviated as the FSA, is an institution that is independent and free from interference by other parties, which have the functions, duties, and authority of regulation, supervision, inspection, and investigation as referred to in the Act". With the release of these laws then the role of FSA is stronger

The duties and authority of the FSA confirmed in Article 7, which states that, in order to carry out the duty of regulation and supervision in the banking sector as referred to in Article 6 a, that FSA has the authority namely: 
(1) conducting regulation and supervision regarding institutional of banks, include licensing for the establishment of banks, opening bank offices, the basic budget, work plan, ownership, management and human resources, mergers, consolidation and acquisitions of banks, as well as the revocation of bank's license; and regulation and supervision of banking activities, such as: sources of funds, provision of funds, hybridization product, and activity in the service sector.

(2) Regulation and supervision on bank health related to the liquidity, profitability, solvency, asset quality, capital adequacy ratio minimum, lending limits, the ratio of loans to deposits, and bank reserves; regulation and supervision of bank statements relating to the health and performance of the bank; regulation and supervision of the debtor information system; regulation and supervision of credit test (credit testing); and regulation and supervision of bank accounting standards.

(3) Regulation and supervision regarding the prudential aspects of the bank, including: a. risk management; a. governance of the bank; a. the principle how to know the customer and anti-money laundering; and c. prevention of terrorism financing and banking crimes.

(4) Inspection of bank.

Furthermore, according to Article 8 take it to carry out duty as setting-where referred to in Article 6, the FSA has the authority to:

a. determine the regulations implementing this Act;

b. determine the legislation in the financial services sector;

c. determine the regulation and FSA decisions;

d. determine the regulation regarding supervision in the financial services sector;

e. determine the policies regarding the implementation of the FSA duty

f. determine the regulation concerning procedures for determination of a written order of the Financial Services Institute and a particular party;

g. determines the regulation of procedures for establishing the statutory manager at the Institute of Financial Services;

h. determines the organizational structure and infrastructure, as well as manage, maintain, and administer its assets and liabilities; and 
i. determine the regulation concerning the procedures for the imposition of sanctions in accordance with the provisions of the legislation in the financial services sector.

Furthermore, in Article 9, it is stated that, in order to carry out the duty of supervision as referred to in Article 6, the FSA has the authority to:

(1) determine operational policy supervision of the financial services activities;

(2) supervising the implementation of supervisory dutys carried out by the Chief of Executive;

(3) conducting surveillance, inspection, investigation, protection of consumers, and any other action against the Institute of Financial Services, the offender, and/or supporting the activities of the financial services referred to in the legislation in the financial services sector;

(4) provide written orders to the Institute of Financial Services and/or a particular party;

(5) appointing statutory managers;

(6) determine the appropriation of the statutory manager;

(7) determine the administrative sanctions against those who conducted violations of the laws and regulations in the financial services sector; and

(8) provide and/or repeal: 1) the business license; 2) The individual licenses; 3) the effectiveness of the registration statement; 4) a registered mark; 5) approval to conduct business; 6) attestation; 7) approval or determination of dissolution; and 8) other determination.

Although there has been moved the functions, duties and authority of regulation and supervision of financial services activities from BI to the FSA but both of these financial institutions continue to implement cooperative relationship. This is manifested by the presence of the Joint Decree of BI and the FSA on October 18, 2013. Cooperation and coordination within the framework of the implementation of dutys BI and the FSA in order to create a stable financial system and sustainable regulated in the Joint Decision with the basic principle is collaborative, improve efficiency, and efectivity, avoid duplication , completing financial sector regulation, and ensure the smooth implementation of the dutys of Bank Indonesia and the FSA. ${ }^{7}$

${ }^{7}$ Nurita Kumala Sari, Bank Indonesia vs Finance Service Authority, http://nuriithaa.blogspot.co.id, 2015/01, accesed on April 2, 2007 
Base on the description above, with the promulgation of FSAA, the duties and authority of the BI switch to the FSA as mandated in Article 34 (1) of BI Act that "The duty of bank supervision will be carried out by the supervisory board for the independent financial services sector, and is formed by legislation. The provision is contrary to Article 5 and Article 6 of FSAA containing that "the FSA has function organized system of regulation and supervision that is integrated to the overall activities in the financial services sector". This shows their conflicts and haziness of norms regarding which institution has the right to regulate banking institutions including sharia, so that giving rise to a conflict of authority among institutions in terms of regulation and supervision of banks and sharia.

To avoid legal uncertainty in supporting the implementation of the duties and authority of the Bank Indonesia and the FSA in the regulation and supervision of banking, so it is necessary cooperation and coordination in line with the BI Act and FSAA, include: ${ }^{8}$

1. Cooperation and coordination in the implementation of the dutys according to the authority.

2. Financial Services Institutions information exchange and management reporting system of banks and finance companies by the Bank Indonesia and the FSA;

3. Use of property and documents that are owned and/or used BI by the FSA,

4. Management BI officials and employees who transferred or employed at the FSA.

Existence of the Board of Commissioners and Sharia Supervisory Board (SSB) in the Bank Supervision.

\section{The Existence of Board of Commissioner (SSB) in Supervision of sharia Banking}

The role of the Board of Commissioners in supervising the bank declared in Article 108 of the Company Act, that the Board of Commissioners only to supervise the management policies, the road general management, both regarding to the Company or the Company's business in this case, including all sharia banking business activities, and to advise the Board of Directors. Supervision and counseling is done for the benefit of the Company and in accordance with the aims and objectives of the Company.

Furthermore provisions concerning Comissioners Board also regulated in Article 28 of the Sharia Banking Act (SBA), especially concerning the terms, amounts, duties, authority, responsibility, and other matters concerning the board of commissioners and directors of Islamic Bank regulated in the articles of association of the Bank Sharia according to the

\section{${ }^{8}$ Ibid.}


provisions of the legislation, the regulations provide the clear responsibilities and firmly to the responsibilities of the Board of Commissioners.

Because of the position of Board of Commissioners (BOC) as an organ of the company, BOC has responsibility to ensure implementation of function for conducting supervision by good faith, prudenctial and responsibility. The negligence of BOC can cause harm to the company, the harm must be accounted by the BOC even to personal liability. ${ }^{9}$

Furthermore, the duties and responsibilities of the Board of Commissioners on banks as regulated in Regulation of Bank Indonesia Year 2009, includes: ${ }^{10}$

(1) The Board of Commissioners has to conduct supervision on the implementation of Good Corporate Governance (GCG) in every business activity of Sharia Enterprises at all levels of the organization

(2) The Board of Commissioners has to supervise the implementation of duties and responsibilities of Board Directors, as well as advising to the Board of Directors.

(3) In conducting supervision, the Board of Commissioners have to monitor and evaluate the implementation of strategic policies of sharia Enterprises and the Board of Commissioners are prohibited involved in the decision-making of operational activities of Sharia enterprise, except the decision making for providing financing to the Board of Directors throughout the authority of the Board of Commissioners is determined in the basis Budget of Sharia Enterprise or in the General Meeting of Shareholders.

(4) The Board of Commissioners has to ensure that the Board of Directors has followed up on audit findings and/or recommendations of the supervision of Bank Indonesia, the internal auditor, the Sharia Supervisory Board and/or the external auditor.

(5) The Board of Commissioners has to notify in written to Bank Indonesia within 7 (seven) days after the discovery, whether it is a violation of legislation in the field of finance and banking as well as a condition that can endanger business continuity sharia enterprise.

(6) In order to support the effective implementation of the duty and responsibilities, the Board of Commissioner has to establish a Risk Monitoring Committee, Remuneration and Nomination Committee and Audit Committee. Appointment of members of

9 Haniah Ilhami, (2009), Responsibility of Sharia Management Council as Authority of Sharia Compliance Supervision for Sharia Banks, Mimbar Hukum, Vol 21, page. 20

${ }^{10}$ Ali Syukron, Op.Cit, Page. 33-34 
committees determined by the Board of Directors based on the decision of the Board of Commissioners Meeting.

(7) The Board of Commissioners has to ensure that the committee has been formed to effectively carry out their duties and must have guidelines and work rules. Guidelines and work rules committee must be evaluated and regularly update, and guidelines and work rules is binding for every member of the Board of Commissioners. Within these guidelines and procedures have to include the work time and meeting arrangements.

(8) The Board of Commissioners must provide the sufficient time to carry out their duties and responsibilities optimally. Minimal meeting conducted 1 (one) time in 2 (two) months and must be attended by at least $2 / 3$ (two thirds) of the members of the Board of Commissioners.

\section{Existence of Sharia Supervisory Board (SSB) in Sharia Banking Supervision}

The existence and role of the Sharia Supervisory Board (SSB) is an independent body that have duty to give direction, consultancy, evaluation, and monitoring (supervision) the activities of sharia banks in order to ensure that the operations of the sharia bank comply (compliance ) against sharia principles as determined by the fatwa and Islamic law. ${ }^{11}$

Sharia Supervisory Board is a uniqueness that is owned by the Islamic financial institutions. This organization consists of Sharia scholars who oversee and monitor the activities of financial institutions to ensure that these institutions comply with the principles of sharia. ${ }^{12}$ The presence of the Sharia Supervisory Board is one of the main things that differentiate between Conventional banks with sharia banks. The main duty of SSB is to supervise the implementation of bank operation and its products so as not to deviate from the rules of sharia. ${ }^{13}$

\section{CONCLUSIONS}

\section{Conclusion}

1. Various regulations concerning sharia banking regulation and supervision, among others, the Banking Act and the Act of Bank Indonesia. Both of these Acts provide a large role in Bank Indonesia in the regulation and supervision of banking; consist of the institutional

\footnotetext{
${ }^{11}$ National Committee of Corporate Governance Policy, (2004), Good Corporate Governance of Indonesia Banking.

${ }^{12}$ Hennie van Grunieng and Zaid Iqbal onSimon Archer and Rifaat Ahmed Abdel Karim, (2007), Islamic Finance: Regulatory Challenge (Singapore: John willey \& Son, page. 28.

${ }^{13}$ Ari Kristin Prasetyoningrum, (2004), Analysis of Economic Factors Effect and Religiosity toward Supervisors and Managers Perceptions on Independence Sharia Supervisory Board (Case Study of Sharia Banking in Indonesia". Thesis, Master of Science in Accounting, Postgraduate Program, Semarang : University of Diponegoro
} 
banks, healty of banks, prudential aspects of the bank, and bank inspection. After issued of FSAA, so the duties and authority of the BI switch to the FSA as mandated in Article 34 (1) of Bank Indonesia Act that "The dutis of bank supervision will be carried out by the supervisory board for the independent financial services sector, and is formed by legislation. The provision is contrary to Article 5 and Article 6 of FSAA containing that "the FSA to function organized system of regulation and supervision that is integrated to the overall activities in the financial services sector". This shows that there are conflicts and vagueness of norms regarding which institution has the right to regulate banking institutions including sharia banking, so that arise a conflict of authority among institutions in terms of regulation and supervision of banking and sharia banking.

2. Existence of each banking supervisors institution in the implementation of the regulation and supervision of sharia banking is in accordance with the role include: the role of BI before the issuance of FSA Act is very strong, as is authorized to enact regulations, giving and revoking the license of institutional and banking business activities, condicting supervision, inspection and the imposition of sanctions, oblige to provide guidance both preventive and repressive. However, the establishment of FSA, the authorized was taken over by the FSA. The authority of BI only related to the matters relating to monetary policy are the policies to achieve and maintain rupiah stability which is done through controlling inflation and exchange rates, the money supply, or the interest rate. The authority of the Board of Commissioners is to supervise the management of the sharia banking and business activities, provide advice to the Board of Directors for the interests of the Company and in accordance with the aims and objectives of the Company. While the SSB role is to supervise and provide guidance, consultation, evaluation of the activities of sharia banks to ensure that the business activities of sharia banks comply with the principles of the sharia as determined by the fatwa and sharia.

\section{Suggestion}

Based on the above conclusions, it can be suggested that:

1. It is necessary reanalyze towards the Financial Services Authority Act (FSAA) in accordance with the rule of Article 6, 8 and 9 of FSAA, because it is still blurring the norm. Article 8 states that the FSA carrying out the duty of supervision as referred to in Article 6"; as well as in Article 9, states the FSA carrying out supervisory duties "as referred to in Article 6". While that is referred to in Article 6, that the duty of the FSA is carrying out the duty, namely a combination of regulation and supervision of banks. In 
addition it should be reviewed again the provision of Article 5 and 6 FSAA contrary to Article 34 (1) Bang Indonesia Act. The lack of consistent can cause legal uncertainty in the implementation of the functions, duties and authority of regulation and banking supervision, which in turn lead to losses for banks in conducting efforts.

2. Because of the duties and authority of the FSA is also too broad, should regulation and supervision of bank institution returned only into duty and authority of Bank Indonesia, such as about licensing and establishment of banks, opening bank offices, the basic budget, work plan, ownership, management and resources human resources, mergers, consolidation and acquisitions of banks. This is because Bank Indonesia is the central bank that it should have the functions, duties and authority to control all activities and institutional banking.

3. The FSA in implementing its functions, duty, and authority to conduct sharia banking regulation and supervision should always coordinate with Bank Indonesia and other regulatory agencies such as the Board of Commissioners and the Sharia Supervisory Board, in order to avoid overlapping duties and authority that can harm the banking institution.

\section{BIBLIOGRAPHY}

\section{Books}

Anwar, Choirul, 2010, "Supervision mechanisms of Sharia Supervisory Board and Bank Indonesia towards Sharia Jateng Bank In Surakarta, Thesis of Program Master, Law Faculty of Sebelas Maret University, Surakarta University.

Hennie van Grunieng and Zaid Iqbal onSimon Archer and Rifaat Ahmed Abdel Karim, 2007, Islamic Finance: The Regulatory Challenge (Singapore: John willey \& Son, page. 28

Ilhami, Haniah, 2009, Responsibility of Sharia Management Council as Authority of Sharia Compliance Supervision for Sharia Banks, Mimbar Hukum, Vol 21

Marzuki, Peter Mahmud, 2004, Legal Research, Jakarta: Kencana

Purba, Anton in Nasution Darmin (2003), Thought Conception of the Financial Services Authority 
Purba, Jaslen Sardanto, 1998, The Role of Bank Indonesia in Supervision and Development Bank in Indonesia (A Juridical Analysis), Result of Reseach, Law Faculty, USU, Medan

Prasetyoningrum Ari Kristin, 2004, Analysis of Economic Factors Effect and Religiosity Toward Supervisors and Managers Perceptions on Independence Sharia Supervisory Board (Case Study of Sharia Banking in Indonesia),Thesis, Master of Science in Accounting, Postgraduate Program, University of Diponegoro, Semarang

Soesastro Hadi, 2005, Thoughts and Economic Problems in Indonesia in the Last Half Century, Jakarta: Kanisius.

Sabirin, Shayril 2003, Struggle Out of Crisis, Yogyakarta: BPEE.

Soerjono Sukamto, 1986. Some Legal Issues in the Framework of Legal Development in Indonesia, Jakarta: UI Press.

\section{World Wide Web}

Sari, Nurita Kumala, Bank Indonesia vs Finance Service Authority available from http://nuriithaa.blogspot.co.id.2015, Accessed on April 2, 200 